\title{
Novel SARS-CoV-2 and COVID-2019 Outbreak: Current Perspectives on Plant-Based Antiviral Agents and Complementary Therapy
}

\author{
Sevgi Gezici ${ }^{1,2 \star}$, Nazim Sekeroglu ${ }^{2,3}$ \\ 1'Department of Molecular Biology and Genetics, Faculty of Science and Literature, Kilis 7 Aralik University, Kilis, TURKEY. \\ ${ }^{2}$ Advanced Technology Application and Research Center (ATARC), Kilis 7 Aralik University, Kilis, TURKEY. \\ ${ }^{3}$ Department of Horticulture, Faculty of Agriculture, Kilis 7 Aralik University, 79000 Kilis-TURKEY.
}

\begin{abstract}
The Severe Acute Respiratory Syndrome Coronavirus 2 (SARS-CoV-2) caused the novel Corona Virus Disease 2019 (COVID-19), which has been defined as a pandemic by the World Health Organization (WHO) in 2020. The rapid global spread of SARS-CoV-2 virus as a global health emergency has emphasized to findeffective treatment strategies in clinical trials. The several drug trials including Lopinavir (LPV) and Ritonavir, Chloroquine (CLQ), Hydroxychloroquine, Favipiravir (FPV), Remdevisir (RDV), Nitazoxanide, Ivermectin and Interferon, have been explored in COVID-19 patients and some of the drugs have been waiting clinical approval for their anti-SARS-CoV-2 activities. Clinical trials are still ongoing to discover promising new multidrug combination treatment for COVID-19 patients. Considering the difficulties to ascertain efficient drug candidates and the lack of specific anti-viral therapies against COVID-19 outbreak, the current management of SARS-CoV-2 should mainly be supportive. From this point of view, enhancing the immune system through medicinal plants with wide range of bioactive compounds, which exhibit antiviral activities, can play significant roles to increase defense barrier in COVID-19 patients. On the other hand, plant-based agents as complementary and alternative therapies have potential advantages to reduce symptoms of this life-threatening disease and could promote the public health. Recently, there has been a remarkable progress in the field of antiviral herbal therapy owing to increasing concerns about the development of drug resistance and limited advances in the field of antiviral drug discovery. This review provides an overview of published information onbiology, genomic structure, replication cycle and pathogenesis of SARS-CoV-2. It also aims to assemble the fact and a scientific intellectual groundwork on development of antiviral herbal therapy on the bases of extensive literature collection.
\end{abstract}

Key words: SARS-CoV-2, COVID-19, Outbreak, Medicinal plants, Antiviral.

\section{INTRODUCTION}

Viral infections have emerged throughout the human history and they caused dramatically outbreakssuch as Cholera, Ebola, Bubonic Plague, AIDS (Acquired Immunodeficiency Syndrome), Influenza, SARS (Severe Acute Respiratory Syndrome), MERS (Middle East Respiratory Syndrome) and currently COVID-19 (causative agent SARS-CoV-2 or 2019-nCoV). The emergence of the viral infections has often been multifactorial and the results of them can altered human civilization. ${ }^{1-4}$ Coronaviruses (CoVs) belong to family of Coronaviridae, Arteriviridae, Roniviridae and Mesoniviridae families. Of which, Coronaviridae is the largest family and includes subfamily of Coronavirinae, that is now classified into four main genera including alpha $(\alpha)$-coronavirus, beta $(\beta)$-coronavirus, gamma $(\gamma)$-coronavirus and delta ( $\delta$ )-coronavirus. Alphacoronaviruses and $\beta$-coronaviruses infect variety of host
Submission Date: 28-4-2020; Revision Date: 16-5-2020; Accepted Date: 20-7-2020

DOI: 10.5530/ijper.54.3s.143 Correspondence: Dr. Sevgi Gezici

Associate Professor, Department of Molecular Biology and Genetics, Faculty of Science and Literature, Kilis 7 Aralik University, Kilis-79000, Merkez/Kilis, TURKEY.

Phone: +90 5376348061 E-mail: drsevgigezici@gmail. com

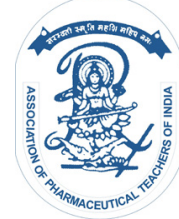

www.ijper.org 
cells and can cause life-threatening pneumonia in humans and some animals such as feline, porcine, canine, mice, bovine, bat and rodent, while $\gamma$-coronavirus and $\delta$-coronavirus are specific of birds, but some of them can also infect other organisms. ${ }^{5-8}$

According to the International Committee for Taxonomy of Viruses, FECV (Feline Enteric Coronavirus) and FIPV (Feline Infectious Peritonitis Virus), the porcine TGEV (Transmissible Gastro-Enteritis Virus), Porcine PEDV (Epidemic Diarrhea Virus), PRCoV (Porcine Respiratory Coronavirus), CCoV (Canina Coronavirus) and human coronaviruses $(\mathrm{HCoV}-229 \mathrm{E}$ and HCoVNL63) are of $\alpha$-coronaviruses. Betacoronaviruses also compromise Murine coronavirus (MHV) and Bovine Coronavirus $(\mathrm{BCoV})$ and human coronaviruses (HCoV-OC43, HCoV-HKU1, SARS-CoV, MERS-CoV and SARS-CoV-2). ${ }^{9,10}$

Although, the history of CoVs began in the 1940's, the first human CoVs subsequently, named as (i) human $\mathrm{CoV}-229 \mathrm{E}(\mathrm{HCoV}-229 \mathrm{E})$ and (ii) $\mathrm{HCoV}-\mathrm{OC} 43$, were reported in the 1960's. ${ }^{1,2,7}$ After that, the virologist tried to identify general structure of CoVs, as well as replication and pathogenesis of them. The studies among the scientist provided to discovery of other new human coronaviruses such as (iii) $\mathrm{HCoV}$ - Hong Kong University 1 (HKU1), (iv) HCoV-NL63, (v) Severe Acute Respiratory Syndrome (SARS)-CoV and (vi) Middle East Respiratory Syndrome (MERS)-CoV., ${ }^{5,11,12}$ Among these coronaviruses, SARS-CoV was identified as a global outbreak in 2003 and it had affected 8422 people in 32 countries, with the mortality of rate of $10-15 \%$. SARS-CoV initially infected the bats and caused the disease by transmitting from bats to the palm musk cat and from there to humans. ${ }^{12-14}$ Then, approximately after ten years, another highly pathogenic coronavirus MERS-CoV epidemic emerged in Saudi Arabia and spread to other Middle Eastern countries in 2013. Although, the major MERS-CoV pandemic was happened in the Republic of Korea, it was observed worldwide at any age of people with the fatality rate of $39 \% .^{11,15,16}$

Following this outbreak, the novel coronavirus namely 2019-nCoV or SARS-COV-2 has been caused COVID19 outbreak emerged in Wuhan State, Hubei Province, China in December 2019. It has spread to more than 180 countries and territories US, Spain, Italy, France, Germany, United Kingdom, China and Iran continue to be the countries hardest-hit. Since, it has been infected many people and caused a high mortality rate in a short period, the World Health Organization (WHO) has declared the new coronavirus outbreak called COVID-19 a pandemic. ${ }^{17,18}$ As of 15 May 2020, more than 4,426,937 confirmed cases of COVID-19 have been reported in many countries and territories, resulting in approximately 301,937 deaths all around the world. Moreover, the number of infected patients with COVID-19 and death from this virus are alarmingly increasing day by day. ${ }^{19,20}$ Since its rapid infection ability from person to person and high mortality rate, finding efficient and accurate therapy strategies are urgently necessary to combat this disaster. Hence, scientists have been racing to understand novel coronavirus disease to reveal possible therapy strategies including drug discovery, therapeutic antibodies, cytokines, nucleic acid-based therapy, vaccines with the potential for treating and preventing coronavirus infections. Among the given strategies, to discover effective drugs, which may be applicable to COVID-19, have been seem to be the most certain option for immediate treatment. Although, no specific drug has been investigated or currently available for COVID-19 cases, clinical trials and evaluations of potential antiviral drug candidates are ongoing at different laboratories. ${ }^{12,21}$

Current researches on developing drugs against many viral diseases undertaken that medicinal plants used in traditional folk medicine have significant importance for the ongoing development of therapeutic agents and broad-spectrum drugs. ${ }^{22-25}$ The information included in this review reveals that possible efforts to search for efficient complementary and alternative medicines from different herbal formulations against emerging coronavirus outbreak that is urgently necessary to reduce overwhelming impacts on worldwide healthcare systems. Moreover, biological properties of coronaviruses and their mechanisms of infection in the host cells, which are necessary to discover useful therapeutic routes for this outbreak, have been summarized in the presented review.

\section{Genomic Structure of Human Coronaviruses}

Coronaviruses are single stranded positive sense RNA viruses encapsulated within a membrane envelopeand their genome comprises approximately 26-32 kilobases nucleotides. In all $\mathrm{CoV}$ s encode five structural proteins: (i) spike protein (S), (ii) hemagglutinin esterase (HE) protein, (iii) membran protein (M), (iv) envelope protein (E), (v) nucleocapsid protein $(\mathrm{N})$, respectively, from outside to inner membrane. ${ }^{26-28}$ These proteins play critical roles for virion assembly, viral replication and transcriptionas well as suppression the host immune response (Figure 1).

(i) S protein, located outside of the virus, are a glycoprotein that gives the typical shape for the virion. These proteins act as cell surface receptor 
proteins for introduce the host cell and interact with membrane proteins. ${ }^{29}$

(ii) Additionally, hemagglutinin esterase (HE) proteins can be found in some beta-coronaviruses in order to strengthen invading mechanism. They help in the attachment and destruction of certain sialic acid receptors that exist on the host cell surface. ${ }^{28,29}$

(iii) $\mathrm{M}$ proteins are glycosylated glycoproteins that are essential for regeneration in the virus cell. They are also necessary to fuse into the host celland bind to $\mathrm{N}$ proteins. ${ }^{12}$

(iv) E proteins are hydrophobic small proteins, covering completely the membrane. They allow attachment to the membrane of viruses and play a key role in the combining of the viral particules in the host cell. ${ }^{12,30}$

(v) N proteins are phosphoproteins that are able to bind viral genomic RNA. These proteins are important for structure, replication andtranscription mechanisms of coronaviruses through interactions with the RNA viral genome. It is also determined that these proteins give information about the pathogenesis in the host cell and virulence of $\mathrm{CoVs} .{ }^{29-31}$

Besides structural proteins, most of the non-structural and accessary proteins are essential for coronaviral replication. Even though, specific roles of each nonstructural proteins (NSPs) and accessory proteins have not been clarified scientifically, most of the NSPs from NSP1 to NSP16 and some of the accessory proteins have been reported to possess specific functions for CoVs replication. ${ }^{16,17}$ Their known functions are summarized in Table 1.

\section{Replication and Infection Mechanisms of Human Coronaviruses}

Coronaviruses are viruses whose genomic material comprises single stranded-positive sense (+ss) RNA that acts as a messenger RNA (mRNA) in the infection cycle. Among all known CoVs, two-thirds of the genome encodes a viral RNA-dependent polymerase materials (RdRp), including two overlapping open reading frames (ORF1a and ORF1b) in the 5'untranslated region (UTR). In this region of the CoVs have been shown to consist of a replicase complex (ORF1a and ORF1b) encoding non-structural proteins (NSPs), when 3' terminus of the CoVs consist of structural proteins including nucleocapsid protein $(\mathrm{N})$ gene, membrane protein $(\mathrm{M})$ gene, envelope protein $(\mathrm{E})$ gene and spike protein (S) gene.These structural canonical proteins, located at the 3 ' terminus of the genome, are not only involved in replication and transcription of the viral genome, but also help to make easier for the virus to enter and multiply into the host cell by suppressing the host's immune system. ${ }^{16,17,32,33}$ Phylogenetic tree and genomic structure of CoVs including COVID-19 (SARS-CoV-2) are given in the Figure 2.

Researchers have released the first full genome sequence of $2019-\mathrm{nCoV}$ by reverse transcription polymerase chain reaction (RT-PCR) methods on 10 January 2020. ${ }^{17,18}$ Ongoing researches have revealed that SARS-CoV-2 has ancestral genomic similarities to SARS-coronaviruses. As of January 31, SARS-CoV-2 whole genome sequences from different laboratories and regions have identified and the data has presented to GISAID (Global Initiative on Sharing All Influenza Data) (https://www.gisaid.org/). As shown in the Figure 2 (a), the genome sequence alignment of different coronaviruses exhibits $54 \%$ identity at whole genome level. NSP coding region shows 58\% identity, suggesting NSPs are more conserved among the CoVs, while structural proteins are less conserved with 43\% identity at the whole genome level of different CoVs. As for SARS-CoV-2 (2019-nCoV), it has a genome structure same as the other $\beta$-CoVs including Bat-(SL) ZC45, Bat-(SL) ZXC21, SARS-CoV and MERS-CoV. ${ }^{16}$ $\mathrm{S}$ proteins of the $\mathrm{CoVs}$ include receptors on the cell surface and these receptors make recognition on the host cells, then the virus can entry into the cells and replication of the CoVs begin with the binding of the host cell surface. Aminopeptidase N, O-acetylated sialic acid, angiotensin-converting enzyme 2 (ACE2), dipeptidyl peptidase 4 (DPP4), transmembrane protease serine 2 (TMPRSS2) and airway trypsin-like protease TMPRSS11D are of the receptors used by human $\mathrm{CoVs}$ to entry the cell membrane of host cells. ${ }^{28-31}$ Human $\mathrm{CoVs}$ and their cellular receptor proteins are summarized in the Table 2 .

The replication of $\mathrm{CoVs}$ begins, after entering the host cell cytoplasm. The viral particules release the RNA genome and the replicase gene products ORF1a and ORF1b that are ready for translation into two polyproteins (pp1a and pp1ab), shown in the Figure 1. After that, $\mathrm{pp} 1 \mathrm{a}$ and $\mathrm{pp} 1 \mathrm{ab}$ are cleaved into almost 16 non-structural proteins (NSPs), which are responsible for assembling replication and transcription complex (RTC) in a double-membran vesicle (DMVs). Subsequently, the full-length positive strand of genomic RNA is converted into a full-length negative-strand template for the synthesis of new genomic RNAs, with the activities of replicase enzymes. 3' end of the genome encodes structural and accessory proteins $(\mathrm{S}$, $\mathrm{E}, \mathrm{M}, \mathrm{N}$ and others such as $\mathrm{HE}$ protein, $3 \mathrm{a} / \mathrm{b}$ protein, $7 \mathrm{a} / \mathrm{b}$ protein, $9 \mathrm{~b} / \mathrm{c}$ protein etc.), necessary for viral replication and transcription, are produced by these 


\begin{tabular}{|c|c|c|c|}
\hline \multicolumn{2}{|c|}{ Proteins of CoVs } & \multicolumn{2}{|r|}{ Specific Functions } \\
\hline \multirow{16}{*}{ 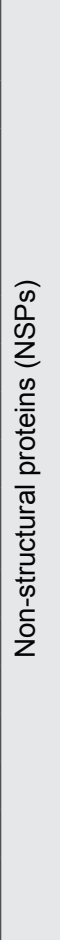 } & NSP-1 & Cellular Saboteur & $\begin{array}{l}\text { Forces the cell to make more virus proteins and cellular mRNA } \\
\text { degradation }\end{array}$ \\
\hline & NSP-2 & Mystery Protein & Unknown \\
\hline & NSP-3 & Untagging and Cutting & $\begin{array}{l}\text { Cuts loose other viral proteins and alters many of the infected } \\
\text { cell's proteins }\end{array}$ \\
\hline & NSP-4 & Bubble Maker & $\begin{array}{l}\text { Constructs double-membrane vesicles and parts for new copies } \\
\text { of the virus }\end{array}$ \\
\hline & NSP-5 & Protein Scissors & Makes most of the cuts and inhibits IFN signaling \\
\hline & NSP-6 & Bubble Factory & Works together with NSP-3 and NSP-4 to make virus bubbles \\
\hline & NSP-7 & Copy Assistants & Make new copies of the RNA genome \\
\hline & NSP-8 & Copy Assistants & Make new copies of the RNA genome \\
\hline & NSP-9 & At the Heart of the Cell & $\begin{array}{l}\text { Infiltrates tiny channels in the infected cell's nucleus and } \\
\text { organizes dimerization }\end{array}$ \\
\hline & NSP-10 & Genetic Camouflage & Camouflages the virus's genes \\
\hline & NSP-11 & Unknown & Unknown \\
\hline & NSP-12 & Copy Machine & Assembles genetic letters into new virus genomes \\
\hline & NSP-13 & Unwinding RNA & Unwinds virus RNA (RNA helicase) and makes new copies \\
\hline & NSP-14 & Viral Proofreader & Corrects and edits the virus genome (exoribonuclease) \\
\hline & NSP-15 & Cleaning Up & Hides the virus RNA from the host cell's immune defenses \\
\hline & NSP-16 & More Camouflage & $\begin{array}{c}\text { Works with NSP-10 and camouflages the virus's genes by } \\
\text { negatively regulating immunity }\end{array}$ \\
\hline \multirow{9}{*}{ 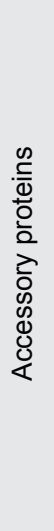 } & ORF3a & Escape Artist & $\begin{array}{l}\text { Pokes a hole in the membrane of the host cell, making it easier } \\
\text { for new viruses to escapeand also triggers inflammation }\end{array}$ \\
\hline & ORF3b & Unknown & Overlaps theRNA but it is not clear \\
\hline & ORF6 & Signal Blocker & $\begin{array}{l}\text { Blocks both signals in the infected cells and some of the cell's } \\
\text { own virus-fighting protein }\end{array}$ \\
\hline & ORF7a & Virus Liberator & $\begin{array}{l}\text { Triggers infected cells to commit suicide and allows more of the } \\
\text { viruses to escape }\end{array}$ \\
\hline & ORF7b & Unknown & Overlaps theRNA but it is not clear \\
\hline & ORF-8 & Mystery Protein & Its function is not clear \\
\hline & ORF9b & Immune System Blocker & Overlaps theRNA and blocks interferon \\
\hline & ORF9c & Unknown & Its function is not clear \\
\hline & ORF10 & Mystery Protein & Unknown \\
\hline
\end{tabular}

new genomic RNAs and they are distributed among the structural genes. ${ }^{34,35}$ (Figure 1 and 2).

The novel coronavirus (SARS-CoV-2), originated from bats is a zoonotic virus that infects human. The virus primarily infects upper respiratory system in human beings. Transmission of COVID-19 infections occurs through respiratory droplet from human to human and touching of contaminated surfaces, as reported in the studies. Even though the common symptoms of the $\mathrm{CoVs}$ infections are similar, each CoVs infection includes unique symptoms. ${ }^{35-38}$ General symptoms of human coronaviruses are summarized in the Table 2. As given in the Table 2, fever, cough, muscle pain, weakness, respiratory symptoms and shortness of breath are of some common symptoms observed in COVID-19. Of which fever and cough have been reported as commonsymptoms in the patients. These common-symptoms can be changed depending on the patient immune response and asymptomatic people do not develop any symptom. ${ }^{10,18,38,39}$

\section{Potential Treatment and Prevention Strategies for Coronaviruses}

Currently, no efficient antiviral therapy is available for emerging COVID-19, but recommended treatment strategies are available. Although, scientists have been devoted to find new antiviral targets that can be $\mathrm{CoVs}$ proteases inhibitors (e.g. lopinavir/ritonavir), polymerases, methyltransferases, replicase inhibitors (e.g. 1,2,4-triazolederivative, remdesivir, disaproxil and lamivudine), kinase signaling pathway inhibitors 
(e.g. trametinib, selumetinib, everolimus, rapamycin, dasatinib and imatinib mesylate), nucleic acid synthesis inhibitors (e.g. gemcitabine, hydrochlorideribavirin and mycophenolic acid), as well as entry inhibitors clinical trials have been ongoing with some of them. ${ }^{12,40}$ Nowadays, plasma and antibodies obtained from the COVID-19 patients have been proposed for one of another potential strategy in treatment. Additionally, numerous researchers in some laboratories and institutes have mainly been focused on development various vaccine strategies, such as using inactivated viruses, live-attenuated viruses, viral vector-based vaccines and recombinant proteins. ${ }^{29,37,41,42}$

In generally, two potential treatment strategies have been employed for coronaviruses-related diseases: (1) Broad spectrum antiviral drugs and (2) anti-CoV drug discovery involves the de novo development. The first strategy possesses possible benefits, if pharmacokinetic and pharmacodynamic properties of the drugs are known in details. As for the second one, it is aimed to develop specific agents based on the genomic and biologic understanding of the individual CoVs. ${ }^{12,37}$

Ribavirin, lopinavir, ritonavir and combination therapy using interferon $\alpha-1$ and corticosteroid, used for SARS-CoV patients have not been found so effective therapeutics that have been clearly revealed by previous reports. In another study, the combination of ritonavir and interferon $\beta-1 \mathrm{a}$ had no significant effect on clinical outcome in the MERS patients, further, the combination of ribavirin, ritonavir; interferon $\alpha$-2a resolved viremia within 2 days after commencement of treatment in a patient with severe MERS had no favorable response. However, the combination therapy of interferon and ribavirin showed the best result for MERS-CoV infection. ${ }^{17,43,44}$

Moreover, broad-spectrum inhibitors such as lycorine, emetine, monensin sodium, mycophenolate mofetil, mycophenolic acid, phenazopyridineand pyrvinium pamoate have showed strong inhibition in replication of human CoVs in a dose and time dependently. In one of the drug research has been revealed that four drugs including chloroquine, chlorpromazine, loperamide and lopinavir from the screening of FDA approved drugs library were able to suppress the replication of MERSCoV, SARS-CoV and HCoV-229E. ${ }^{44,45}$

To identify potential antiviral agents against novel COVID-19, current researches have been primarily tried previous drugs used for the SARS- and MERS-CoV infections. Since SARS-CoV-2 is a newly discovered pathogen, drug trials in the management of patients with SARS-CoV-2 infection are still ongoing. Increasing understanding of the basic information about novel $\mathrm{CoVs}$ will provide opportunities for design specific and efficient therapeutics in the near future. ${ }^{25,37,38}$

\section{Antiviral Effects of Medicinal Plants and Phytochemicals}

Currently, approved remedy for management of many types of viruses is limited and often costly and ineffective because of viral multidrug resistance and toxic side effects. In that case, plant-based therapy could offer an alternative treatment for virus-related infections. Hence, it is necessary to examine natural

\begin{tabular}{|c|c|c|c|c|}
\hline \multicolumn{5}{|c|}{ Table 2: Human Coronaviruses, Cell Surface Receptors and Symptoms of CoVs. } \\
\hline Human CoVs & Classification & Natural Host & Symptoms & Receptor Proteins \\
\hline HCoV-229E & a-coronavirus & Bats & $\begin{array}{c}\text { Mild respiratory tract } \\
\text { infections }\end{array}$ & $\begin{array}{c}\text { Human aminopeptidase N } \\
\text { (CD13) }\end{array}$ \\
\hline HCoV-OC43 & B-coronavirus & Cattle & $\begin{array}{c}\text { Mild respiratory tract } \\
\text { infections }\end{array}$ & 9-O-acetylated sialic acid \\
\hline SARS-CoV & B-coronavirus & Palm civets & $\begin{array}{c}\text { Severe acute respiratory } \\
\text { infections, 10\% mortality } \\
\text { rate }\end{array}$ & $\begin{array}{c}\text { Angiotensin-converting } \\
\text { enzyme 2 (ACE2) }\end{array}$ \\
\hline HCoV-NL63 & a-coronavirus & Bats, palm civets & $\begin{array}{c}\text { Mild respiratory tract } \\
\text { infections }\end{array}$ & $\begin{array}{c}\text { Angiotensin-converting } \\
\text { enzyme 2 }\end{array}$ \\
\hline HCoV-HKU1 & B-coronavirus & Mice & $\begin{array}{c}\text { Pneumonia, lung } \\
\text { inflammation }\end{array}$ & $\begin{array}{c}\text { 9-O-acetylated sialic acid } \\
\text { (ACE2) }\end{array}$ \\
\hline MERS-CoV & B-coronavirus & Bats, camels & $\begin{array}{c}\text { Severe acute respiratory } \\
\text { infections, 37\% mortality } \\
\text { rate }\end{array}$ & $\begin{array}{c}\text { Dipeptidyl peptidase 4 } \\
\text { (DPP4) }\end{array}$ \\
\hline SARS-CoV-2 & B-coronavirus & Bats & $\begin{array}{c}\text { Fever, cough, muscle pain, } \\
\text { weakness, respiratory } \\
\text { symptoms, shortness of } \\
\text { breath and death, }\end{array}$ & $\begin{array}{c}\text { Angiotensin-converting } \\
\text { enzyme 2 (ACE2) } \\
\text { and transmembrane } \\
\text { proteaseserine 2 } \\
\text { (TMPRS2) }\end{array}$ \\
\hline
\end{tabular}


antiviral phytochemicals used for successfully drug delivery applications in overcoming the multiple biological barriers. ${ }^{33,46}$

A number of medicinal plants, possessing diverse pharmacological properties including antiviral activites, havebeen used in traditional medicinefor thousand of years. In recent years, medicinal plants, which are good sources for drug discovery and pharmaceutical industry, have been preferred by the people for their primary healthcare. The beneficial therapeutic effects of plantbased products typically result from the phytochemicals found in the plants. Various phytochemicals derived from medicinal plants including alkaloids, steroids, lignans, diterpenoid lactones, aliphatics, glycosides etc. have showed to induce antiviral effects and prevent several viral diseases. As synthetic drugs are not available towards most of the viruses, so reserachers have been focused on to search for drugs obtained from different herbal formulations. Almost all around the world, people have been recently tend to use medicinal plants as complementary and alternative medicines in order to enhance immune system for fighting COVID19. ${ }^{17,47,48}$ Accordingly, hundreds of medicinal plants and secondary metabolites have been displayed, identifiedand analyzed in both preclinical and clinical trials for their medicinal activities; however, some have demonstrated significant antiviral activity in prevention of various viral diseases. Many medicinal plants individually or in combination with different formulations including decoctions, leaf powder, infusions, pastes and pills have been recommended in the eradication and management of various viral infections. ${ }^{18,49}$ Antiviral herbal medicines have been used in many historic viral diseases, the findings related to antiviral medicinal plants and phytochemicals are collected in Table 3.
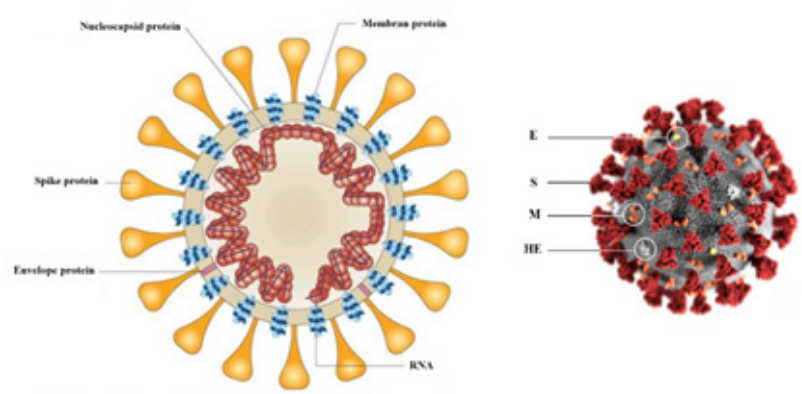

Figure 1: Structure of Coronaviruses (modified from https:// www.id-hub.com/).

(a)
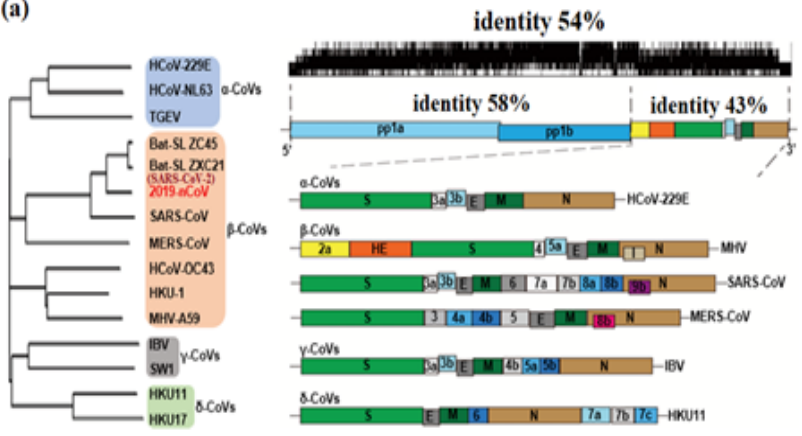

(b)

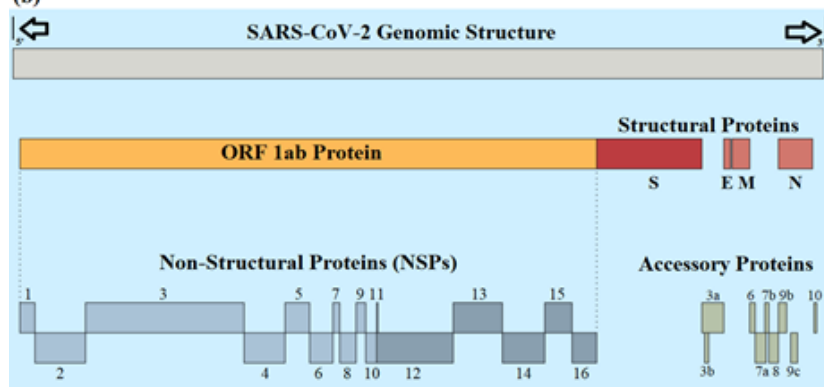

Figure 2: (a) Phylogenetic Tree and Genomic Organization of the Human Coronaviruses16 (b) SARS-CoV-2 Genomic Structure (modified from https://www.nytimes.com/interactive/science/coronavirus).

\begin{tabular}{|c|c|c|c|}
\hline Medicinal Plant & Extract/Phytochemicals & Antiviral Activity & References \\
\hline \multirow{2}{*}{ Aloe vera $\mathrm{L}$. } & Glycerine extract & Herpes simplex virus type 2 (HSV-2) & 46,50 \\
\hline & Anthraquinones & Hepatitis B virus & 51 \\
\hline Eucalyptus globulus Labill. & EOs & $\begin{array}{l}\text { Herpes simplex virus (HSV-1) and } \\
\text { Influenzavirus A (H1N1) }\end{array}$ & 52 \\
\hline $\begin{array}{l}\text { Baccharis gaudichaudiana, } \\
\text { B. spicata and B. anomala }\end{array}$ & Extracts & $\begin{array}{c}\text { Bovine herpes virus } 1 \text { and herpes simplex } \\
\text { virus (HSV-1) }\end{array}$ & 53 \\
\hline \multirow{4}{*}{ Melissa officinalis L. } & \multirow{4}{*}{ Extracts } & Avian infectious bronchitis virus (IBV) & 54 \\
\hline & & $\begin{array}{c}\text { Herpes simplex virus type } 1 \text { (HSV-1), type } 2 \\
\text { (HSV-2) and an acyclovir-resistant strain of } \\
\text { HSV-1 (ACVres) }\end{array}$ & 55 \\
\hline & & Herpes simplex virus (HSV-1) & 56,57 \\
\hline & & Herpes simplex virus (HSV) & 58,59 \\
\hline
\end{tabular}




\begin{tabular}{|c|c|c|c|}
\hline & \multirow{3}{*}{ EOs (lemon balm oil) } & Avian influenza virus (AIV) subtype H9N2 & 60 \\
\hline & & Herpes simplex virus (HSV-1 and HSV-2) & 61,62 \\
\hline & & Zika virus (ZIKV) & 63 \\
\hline & Extracts and EOs & $\begin{array}{l}\text { Herpes simplex virus (HSV), vaccinia virus, } \\
\text { Semliki Forest and Newcastle virus }\end{array}$ & 64 \\
\hline & Extracts and rosmarinic acid & Enterovirus 71 (EV71) & 65 \\
\hline Alpinia galanga L. & Extracts and bioactive compounds & Novel coronavirus (SARS-CoV-2) & 66 \\
\hline $\begin{array}{l}\text { Chamomilla recutita L. } \\
\text { (syn. Matricaria recutita L.) }\end{array}$ & Extracts and EOs & Herpes simplex virus (HSV), poliovirus & 67,68 \\
\hline Sambucus nigra L. & Extracts and bioactive compounds & $\begin{array}{l}\text { Human immunodeficiency virus (HIV), feline } \\
\text { immunodeficiency virus (FIV), influenza } \\
\text { virus, parainfluenza virus, human rhinovirus } \\
\text { B, coxsackievirus, adenovirus Cand } \\
\text { respiratory syncytial virus. }\end{array}$ & $68-72$ \\
\hline Citrus sp. & $\begin{array}{l}\text { Extracts and bioactive compounds } \\
\text { (hesperidin, hesperetin, naringenin, } \\
\text { tangeretin, nobiletin) }\end{array}$ & $\begin{array}{l}\text { Influenza A virus, hepatitis (B and C) } \\
\text { virus,human respiratory syncytial virus } \\
\text { (RSV), Vesicular stomatitis virus } \\
\text { (VSV), Arenavirus Lassa virus } \\
\text { (LASV) and } \\
\text { novel coronavirus (SARS-CoV-2) }\end{array}$ & $22,66,73-75$ \\
\hline \multirow{10}{*}{ Rosmarinus officinalis $\mathrm{L}$. } & $\begin{array}{l}\text { oleanolic acid, rosmarinic acid and } \\
\text { eucalyptol }\end{array}$ & $\begin{array}{l}\text { Herpes simplex virus (HSV-1) and hepatitis } \\
\text { B virus (HBV) }\end{array}$ & 76 \\
\hline & \multirow{4}{*}{ Extracts } & $\begin{array}{l}\text { Herpes simplex virus (HSV-1) and an } \\
\text { acyclovir-resistant strain of HSV-1 (ACVres) }\end{array}$ & 55 \\
\hline & & $\begin{array}{c}\text { Herpes simplex virus type } 1 \text { (HSV-1), type } \\
2 \text { (HSV-2) Newcastle disease virus (NDV), } \\
\text { herpes simplex, vaccinia, Semliki Forestand } \\
\text { West Nile viruses }\end{array}$ & 77 \\
\hline & & $\begin{array}{c}\text { Measles, Mumps, Vesicular Stomatitis Virus } \\
\text { (VSV) and Herpes simplex virus type-2 } \\
\text { (HSV-2). }\end{array}$ & 78 \\
\hline & & $\begin{array}{l}\text { Herpes simplex virus type } 1 \text { (HSV-1), type } \\
2 \text { (HSV-2) }\end{array}$ & 79 \\
\hline & EOs (rosemary) and 1.8 cineole & Hepatitis A virus (HAV) & 80 \\
\hline & EOs (rosemary) and rosemarinic acid & Zika virus (ZIKV) & 63 \\
\hline & \multirow{2}{*}{ EOs (rosemary) } & Herpes simplex virus type 1 (HSV-1) & 81 \\
\hline & & Avian infectious bronchitis (IBV), & 82 \\
\hline & Extracts and cineol & $\begin{array}{l}\text { Influenza A H1N1 and oral herpes simplex } \\
\text { HSV-1 }\end{array}$ & 52 \\
\hline $\begin{array}{c}\text { Cinnamomum zeylanicum } \\
\text { Blume }\end{array}$ & EOs & $\begin{array}{c}\text { Herpes simplex virus (HSV-1) and Influenza } \\
\text { virus A (H1N1) }\end{array}$ & 52 \\
\hline
\end{tabular}




\begin{tabular}{|c|c|c|c|}
\hline \multirow{9}{*}{ Glycyrrhiza glabra L. } & $\begin{array}{l}\text { Extracts and bioactive contituents } \\
\text { (glycyrrhizin glycocoumarin, } \\
\text { lycopranocoumarin and lycocarbon A) }\end{array}$ & $\begin{array}{c}\text { Herpes simplex, Epstein-Barr, human } \\
\text { cytomegalovirus, hepatitis A, B and C, } \\
\text { influenza, HIV, varicella zoster virus (VZV) } \\
\text { and SARS coronaviruses }\end{array}$ & 83 \\
\hline & Extracts and kanzonol V & Zika virus (ZIKV) & 63 \\
\hline & $\begin{array}{l}\text { Extracts, glycyrrhizin and glycyrrhizic } \\
\text { acid }\end{array}$ & $\begin{array}{c}\text { Hepatitis (B and C), Human } \\
\text { immmunodeficiency virus (HIV-1), herpes } \\
\text { simplex virus (HSV) and SARS coronavirus }\end{array}$ & $84-88$ \\
\hline & Extracts & $\begin{array}{c}\text { Herpes simplex virus (HSV-1) and influenza } \\
\text { A virus }\end{array}$ & 89,90 \\
\hline & \multirow{4}{*}{ Extracts and glycyrrhizin } & Swine epidemic diarrhea virus & 91 \\
\hline & & Hepatitis A, B and C & 92 \\
\hline & & $\begin{array}{c}\text { Influenza A virus (FLUAV), Rift Valley fever } \\
\text { virus (RVFV), Human metapneumotic } \\
\text { virus (HMPV), echovirus } 1 \text { (EV1), } \\
\text { chikungunya virus (CHIKV), Ross River } \\
\text { virus (RRV), Zika virus (ZIKV), hepatitis C } \\
\text { virus (HCV), Sindbis virus (SINV), HIV-1, } \\
\text { cytomegalovirus (CMV), hepatitis B virus } \\
\text { (HBV) and herpes simplex virus type } 1 \\
\text { (HSV-1), }\end{array}$ & 93 \\
\hline & & $\begin{array}{l}\text { influenza virus, SARS coronavirus and } \\
\text { Human immmunodeficiency virus (HIV) }\end{array}$ & 83,92 \\
\hline & glycyrrhizic acid & $\begin{array}{l}\text { Kaposi's sarcoma herpes virus (KSHV) and } \\
\text { hepatitis B virus }\end{array}$ & 94,95 \\
\hline Taraxacum officinale L. & Extracts & $\begin{array}{c}\text { Hepatitis } \mathrm{C} \text { virus (HCV), Influenza virus type } \\
\text { A (H1N1) }\end{array}$ & 96 \\
\hline \multirow[b]{2}{*}{ Vitis spp. } & Methanol extract from $V$. labrusca & \multirow[b]{2}{*}{$\begin{array}{l}\text { Simian (SA-11) and human (HCR3) } \\
\text { rotaviruses }\end{array}$} & \multirow[b]{2}{*}{97} \\
\hline & $\begin{array}{c}\text { Methanol extract from } V \text {. } \\
\text { macrocarpon }\end{array}$ & & \\
\hline \multirow{3}{*}{ Cistus spp. } & Extracts from C. laurifolius & Parainfluenza - $3(\mathrm{PI}-3)$ & 98 \\
\hline & $\begin{array}{l}\text { Extracts from } C \text {. incanus subsp. } \\
\text { tauricus }\end{array}$ & $\begin{array}{l}\text { Influenza virus (H1N1, H5N1 and H7N7), } \\
\text { Pathogenic avian influenza virus (HPAIV) }\end{array}$ & 99 \\
\hline & $\begin{array}{l}\text { Extracts from } C \text {. incanus subsp. } \\
\text { tauricus }\end{array}$ & Influanza $A$ and $B$ virus and other viruses & 100 \\
\hline Tamarix nilotica & Hydro alcoholic extract & $\begin{array}{l}\text { Herpes simplex-1 virus (HSV) and } \\
\text { poliomyelitis-1 virus (POLIO) }\end{array}$ & 101 \\
\hline \multirow{3}{*}{ Olea europea L. } & $\begin{array}{l}\text { Olea leaf and compounds (oleanolic } \\
\text { acid and calcium elenolate) }\end{array}$ & $\begin{array}{l}\text { Herpes simplex, polio viruses, rhinoviruses, } \\
\text { mycoviruses, coxsackie virus, Varicella } \\
\text { zoster, encephalo myocarditis }\end{array}$ & 102 \\
\hline & Olea leaf and extracts & $\begin{array}{l}\text { Herpes simplex virus (HSV-1), infectious } \\
\text { laryngotracheitis viruses, Newcastle } \\
\text { disease virus (NDV) and rhesus rotavirus }\end{array}$ & 103-107 \\
\hline & $\begin{array}{l}\text { oleuropein glycosides and } \\
\text { their enzyme hydrolysates [2- } \\
\text { (4-hydroxyphenyl) ethyl and 2- } \\
\text { (3,4-dihydroxyphenyl)] }\end{array}$ & $\begin{array}{l}\text { Rotavirus, rhinovirus, parvovirus, hepatitis, } \\
\text { Epstein-Barr, herpes simplex, influenza, } \\
\text { varicella zoster, cat leukemia viruses and } \\
\text { viral hemorrhagic septicemia virus (VHSV) }\end{array}$ & 108,109 \\
\hline \multirow[t]{3}{*}{ Salvia officinalis L. } & Extracts & $\begin{array}{c}\text { Avian infectious bronchitis virus (IBV), } \\
\text { Herpes simplex virus (HSV-1 and HSV-2), } \\
\text { Measles, Mumps and Vesicular Stomatitis } \\
\text { Virus (VSV) }\end{array}$ & $54,57,78$ \\
\hline & EOs, 1,8-cineol and $\alpha$-thujone & SARS-CoV and HSV-1 & 110 \\
\hline & Extracts and EOs & Zika virus (ZIKV) & 63 \\
\hline
\end{tabular}




\begin{tabular}{|c|c|c|c|}
\hline \multirow[t]{2}{*}{ Mentha piperita L. } & Extracts & $\begin{array}{l}\text { Avian infectious bronchitis virus (IBV), } \\
\text { respiratory syncytial virus (RSV), Herpes } \\
\text { simplex virus type } 1 \text { (HSV-1), type } 2 \text { (HSV- } \\
\text { 2) and an acyclovir-resistant strain of HSV-1 } \\
\text { (ACVres) }\end{array}$ & $54,55,57,111$ \\
\hline & $\begin{array}{l}\text { Aqueous extract, hydroalcoholic } \\
\text { extract and EOs }\end{array}$ & Herpes-simplex virus (HSV-1 and HSV-2) & 112 \\
\hline \multirow[t]{2}{*}{ Origanum vulgare $\mathrm{L}$. } & Extracts & $\begin{array}{l}\text { Avian infectious bronchitis virus (IBV), } \\
\text { equine arteritis virus (EAV), feline calicivirus } \\
\text { (FCV), canine distemper virus (CDV), } \\
\text { canine adenovirus (CAV) and canine } \\
\text { cororavirus (CCoV) }\end{array}$ & 54,113 \\
\hline & Extracts and bioactive compounds & $\begin{array}{c}\text { Respiratory syncytial virus (RSV), } \\
\text { Coxsackievirus B3 (CVB3), herpes simplex } \\
\text { virus type } 1 \text { (HSV-1) and nonenveloped } \\
\text { murine norovirus (NMN) }\end{array}$ & 114,115 \\
\hline \multirow[t]{2}{*}{ Thymus vulgaris $\mathrm{L}$. } & Extracts & $\begin{array}{l}\text { Avian infectious bronchitis virus (IBV), } \\
\text { Measles, Mumps, Vesicular Stomatitis Virus } \\
\text { (VSV)and Herpes-simplex virus (HSV-1 and } \\
\text { HSV-2) }\end{array}$ & $54,78,112$ \\
\hline & EOs & Herpes-simplex virus (HSV-1) & 116 \\
\hline $\begin{array}{l}\text { Thymus capitatus (L.) } \\
\text { Hoffmans. and Link }\end{array}$ & EOs & $\begin{array}{c}\text { Herpes simplex virus (HSV-1 and HSV-2), } \\
\text { Echovirus } 11 \text { (ECV11) and Adenovirus } \\
\text { (ADV) }\end{array}$ & 117,118 \\
\hline Iresine herbstii Hook. & $\begin{array}{l}\text { Acetone, dichloromethane, ethanol } \\
\text { and petroleum ether extracts }\end{array}$ & Avian Newcastle disease virus & 119 \\
\hline \multirow{3}{*}{ Ocimum bacilium $\mathrm{L}$. } & Aqueous extract & Herpes-simplex virus (HSV-1) & 112 \\
\hline & $\begin{array}{l}\text { Extracts and monoterpenes } \\
\text { (camphor, thymol, linalool and } \\
1,8 \text {-cineole) }\end{array}$ & Bovine viral diarrhoea virus (BVDV) & 120 \\
\hline & $\begin{array}{l}\text { Extracts and purified compounds } \\
\text { (apigenin, linalool and ursolic acid) }\end{array}$ & $\begin{array}{c}\text { Herpes viruses (HSV), adenoviruses (ADV), } \\
\text { hepatitis B virus), coxsackievirus B1 (CVB1) } \\
\text { and enterovirus } 71 \text { (EV71) }\end{array}$ & 121 \\
\hline Solanum paniculatum $\mathrm{L}$. & Extracts and compounds & $\begin{array}{c}\text { Herpes-simplex virus (HSV-1), murine } \\
\text { encephalomyocarditis virus, Equine } \\
\text { herpesvirus-1 (EHV-1) }\end{array}$ & $122-124$ \\
\hline Tinospora cordifolia & Extracts & $\begin{array}{l}\text { Hepatitis A virus, human influenza virus } \\
\text { (HIV) }\end{array}$ & 48,125 \\
\hline Curcuma longa L. & Extracts and curcumin & $\begin{array}{c}\text { Dengue virus (serotype 2), herpes simplex } \\
\text { virus, human immunodeficiency virus type } 1 \\
\text { (HIV-1), Zika and Chikungunya viruses }\end{array}$ & $68,126,127$ \\
\hline Rhus coriaria L. & Extracts & $\begin{array}{c}\text { Acyclovir resistant HSV-1 and hepatitis B } \\
\text { virus (HBV) }\end{array}$ & 128,129 \\
\hline Allium sativum $\mathrm{L}$. & EOs & Novel coronavirus (SARS-CoV-2) & 130 \\
\hline
\end{tabular}

\section{CONCLUSION}

Coronaviruses $(\mathrm{CoVs})$ are one of the largest families of viruses that interact with components of host cells at many levels, suggesting this causes the pathogenesis. After SARS and MERS epidemic, many genetic and molecular mechanisms of the human CoVs have been explored, but there are some challenges about the new highly pathogenic SARS-CoV-2 coronavirus and COVID-19 outbreak. One of the main reason for that RNA viruses can quickly modified theirgenomes, therefore the identified agents, drugs or vaccines are not properly evaluated for in vitro and in vivo studies.

Complementary therapy with medicinal plants are gaining popularity in the worldwide due to numerous advantages such as less expensive, more accessible, less toxicity and resistance, better patient tolerance and fewer or no side effects. Taken together, a revival of interest in medicinal plants for management of viral diseases that resulting in using medicinal plants in complementary and alternative medicine. Besides, they could serve as a source of antiviral drugs for pharmaceutical industry, due to their rich source of bioactive compounds and 
benefits. The literature survey presented in this review has clearly proved that medicinal plants and their bioactive compounds have promising therapeutic potential towards virus infections. Since the lack of experimental and scientific evidence about effective compounds, efficacy, effectiveness, pharmacokinetics, quality and safety of herbal medicine, further clinical and standardization studies should be examined using the plants and phytochemicals to ensure their effective dosage and safety formulations and also explore their mechanism of action.

\section{ACKNOWLEDGEMENT}

Authors would like to thank the authors of the referenced papers. This review is a bundle of many valuable scientific studies.

\section{CONFLICT OF INTEREST}

Authors solely declare no conflict of interest regarding authorship and/or publication of this review.

\section{ABBREVIATIONS}

ACE2: Angiotensin-converting enzyme 2; AIV: Avian influenza virus; CLQ: Chloroquine; CMV: Cytomegalovirus; COVID-19: Corona Virus Disease 2019; DMV: Double-membran vesicle; DPP4: Dipeptidyl peptidase 4; E: Envelope protein; EHV1: Equine herpesvirus-1; FDA: Food and Drug Administration; FPV: Favipiravir; HBV: Hepatitis B virus; HE: Hemagglutinin esterase; HIV: Human immunodeficiency virus; HKU1: HCoV- Hong Kong University 1; HMPV: Human metapneumotic virus; HSV: Herpes simplex virus; IBV: Avian infectious bronchitis virus; KSHV: Kaposi's sarcoma herpes virus; LASV: Arenavirus Lassa virus; LPV: Lopinavir; M: Membran protein; MERS: Middle East Respiratory Syndrome; N: Nucleocapsid protein; NDV: Newcastle disease virus; NMN: Non-enveloped murine norovirus; NSPs: Non-Structural Proteins; ORF: Open reading frame; PI-3: Parainfluenza - 3; POLIO: Poliomyelitis-1 virus; RDV: Remdevisir; RSV: Respiratory syncytial virus; RTC: Replication and transcription complex; RVFV: Rift Valley fever virus; S: Sspike protein; SARS: Severe Acute Respiratory Syndrome; SARS-CoV-2 (2019-nCoV): The Severe Acute Respiratory Syndrome Coronavirus 2; SINV: Sindbis virus; TMPRSS2: Transmembrane protease serine 2; VSV: Vesicular stomatitis virus; VZV: Varicella zoster virus; WHO: World Health Organization; ZIKV: Zika virus.

\section{REFERENCES}

1. Cheever FS, Daniels JB, Pappenheimer AM, and Bailey OT. A murine virus (JHM) causing disseminated encephalomyelitis with extensive destruction of myelin: I. Isolation and biological properties of the virus. The Journal of Experimental Medicine 1949;90(3):181-94. https://doi.org/10.1084/ jem.90.3.181.

2. Geller C, Varbanov M, and Duval RE. Human coronaviruses: insights into environmental resistance and its influence on the development of new antiseptic strategies. Viruses 2012;4(11):3044-68. https://doi.org/10.3390/ v4113044.

3. Bale Jr JF. Emerging viral infections. Seminars in Pediatric Neurology 2012;19(3):152-7. https://doi.org/10.1016/j.spen.2012.02.001.

4. Rodriguez-Morales AJ, Bonilla-Aldana DK, Balbin-Ramon GJ, Rabaan AA, Sah R, Paniz-Mondolfi A,... and Esposito $S$. History is repeating itself: Probable zoonotic spillover as the cause of the 2019 novel Coronavirus Epidemic. Le Infezioni in Medicina 2020;28(1):3-5.

5. Lau SK, Woo PC, Yip CC, Tse H, Tsoi HW, Cheng VC,... and So LY. Coronavirus HKU1 and other coronavirus infections in Hong Kong. Journal of Clinical Microbiology 2006;44(6):2063-71. https://doi.org/10.1128/ JCM.02614-05.

6. King AM, Lefkowitz E, Adams MJ, and Carstens EB. (Eds.). Virus taxonomy: ninth report of the International Committee on Taxonomy of Viruses. (Vol. 9). Elsevier; 2011

7. Walsh EE, Shin JH, and Falsey AR. Clinical impact of human coronaviruses 229E and OC43 infection in diverse adult populations. The Journal of Infectious Diseases 2013;208(10):1634-42. https://doi.org/10.1093/infdis/ jit393.

8. Kanwar A, Selvaraju S, and Esper F. Human Coronavirus (HCoV) Infection Among Adults in Cleveland, Ohio: An Increasingly Recognized Respiratory Pathogen. In Open Forum Infectious Diseases 2017;4(2):1-6, Oxford University Press. https://doi.org/10.1093/ofid/ofx052.

9. Chan JF, Lau SK, To KK, Cheng VC, Woo PC, and Yuen KY. Middle East respiratory syndrome coronavirus: another zoonotic betacoronavirus causing SARS-like disease. Clinical Microbiology Reviews 2015;28(2):465-522. https://doi.org/110.1128/CMR.00102-14.

10. Zhou F, Yu T, Du R, Fan G, Liu Y, Liu Z,... and Guan L. Clinical course and risk factors for mortality of adult inpatients with COVID-19 in Wuhan, China: a retrospective cohort study. The Lancet. 2020;395(10229):1054-62. https:// doi.org/10.1016/S0140-6736(20)30566-3.

11. Park SY, Lee JS, Son JS, Ko JH, Peck KR, Jung Y,... and Shi H. Post-exposure prophylaxis for Middle East respiratory syndrome in healthcare workers. Journal of Hospital Infection 2019;101(1): 42-6. https://doi.org/10.1016/j. jhin.2018.09.005.

12. Pillaiyar T, Meenakshisundaram S, and Manickam M. Recent discovery and development of inhibitors targeting coronaviruses. Drug Discovery Today 2020;1-21. https://doi.org/10.1016/j.drudis.2020.01.015.

13. Pene F, Merlat A, Vabret A, Rozenberg F, Buzyn A, Dreyfus $F, \ldots$ and Bin Cao MD. Coronavirus 229E-related pneumonia in immunocompromised patients. Clinical Infectious Diseases 2003;37(7):929-32. https://doi. org/10.1086/377612.

14. World Health Organization (WHO, 2014) Middle East respiratory syndrome coronavirus (MERS-CoV) summary and literature update-as of 20 January. Geneva, Switzerland, WHO.

15. World Health Organization (WHO, 2019) Clinical mamagment of severe acute respiratory infection when MERS-CoV infection is suspected: interim guidance. Available at: http://www.who.int/iris/handle/10665/178529 (Accessed 17 April 2019) 2019.

16. Chen Y, Liu Q, and Guo D. Emerging coronaviruses: genome structure, replicationand pathogenesis. Journal of Medical Virology 2020;92(4):418-23.

17. Paraskevis D, Kostaki EG, Magiorkinis G, Panayiotakopoulos G, Sourvinos G, and Tsiodras S. Full-genome evolutionary analysis of the novel corona virus (2019-nCoV) rejects the hypothesis of emergence as a result of a recent recombination event. Infection Genetics and Evolution 2020;79:104212. https://doi.org/10.1016/j.meegid.2020.104212.

18. Xu Z, Shi L, Wang Y, Zhang J, Huang L, Zhang C,... and Tai Y. Pathological findings of COVID-19 associated with acute respiratory distress syndrome. 
The Lancet Respiratory Medicine. 2020;8(4):420-2 https://doi.org/10.1016/ S2213-2600(20)30076-X.

19. World Health Organization (WHO, 2020). Novel Coronavirus (2019-nCoV) situation report-109 [published online ahead of print May 9, 2020]. https://www. who.int/docs/defaultsource/coronaviruse/situationreports/20200508covid19-sitrep-109.pdf?sfvrsn=68f2c632_6.

20. GISAID (Global Initiative on Sharing All Influenza Data (https://www.gisaid. org/).

21. Xui J, Shi PY, Li H, Zhou J. Broad Spectrum Antiviral Agent Niclosamide and Its Therapeutic Potential. ACS Infectious Diseases 2020; https://doi. org/10.1021/acsinfecdis.0c00052.

22. Cheng L, Zheng W, Li M, Huang J, Bao S, Xu Q, Ma Z. Citrus Fruits Are Rich in Flavonoids for Immunoregulation and Potential Targeting ACE2. Preprints. 2020;1-13. https://www.preprints.org/manuscript/202002.0313/v1.

23. Sekeroglu N, Gezici S, Coronavirus Pandemic and Some Turkish Medicinal Plants. Anatolian Clinic the Journal of Medical Sciences 2020;25(Suppl-1):163-182. https://doi.org/10.21673/anadoluklin.724210.

24. Luo H, Tang QL, Shang YX, Liang SB, Yang M, Robinson N, Liu JP. Can Chinese medicine be used for prevention of corona virus disease 2019 (COVID-19)? A review of historical classics, research evidence and current prevention programs. Chinese Journal of Integrative Medicine 2020;1-8. https://doi.org/10.1007/s11655-020-3192-6.

25. Ni L, Zhou L, Zhou M, Zhao J, Wang DW. Combination of western medicine and Chinese traditional patent medicine in treating a family case of COVID-19 in Wuhan. Frontiers in Medicine 2020;1-5. https://doi.org/10.1007/s11684020-0757-x.

26. Gorbalenya AE, Enjuanes L, Ziebuhr J, Snijder EJ. Nidovirales: evolving the largest RNA virus genome. Virus Research 2006;117(1):17-37. https://doi. org/10.1016/j.virusres.2006.01.017.

27. Du L, He Y, Zhou Y, Liu S, Zheng BJ, Jiang S. The spike protein of SARSCoV - a target for vaccine and therapeutic development. Nature Reviews Microbiology 2009;7(3):226-36. https://doi.org/10.1038/nrmicro2090.

28. Huang X, Dong W, MilewskaA, GoldaA, QiY, Zhu QK, et al. Human coronavirus HKU1 spike protein uses O-acetylated sialic acid as an attachment receptor determinant and employs hemagglutinin-esterase protein as a receptordestroying enzyme. Journal of Virology 2015;89(14):7202-13. https://doi. org/10.1128/JVI.00854-15.

29. Wu, Y. Compensation of ACE2 function for possible clinical management of 2019-nCoV-induced acute lung injury. Virologica Sinica 2020;1-3. https://doi. org/10.1007/s12250-020-00205-6

30. Wu K, Li W, Peng G, Li F. Crystal structure of NL63 respiratory coronavirus receptor-binding domain complexed with its human receptor. Proceedings of the National Academy of Sciences 2009;106(47):19970-4. https://doi. org/10.1073/pnas.0908837106.

31. Bertram S, Dijkman R, Habjan M, Heurich A, Gierer S, Glowacka I, et al. TMPRSS2 activates the human coronavirus $229 \mathrm{E}$ for cathepsin-independent host cell entry and is expressed in viral target cells in the respiratory epithelium. Journal of Virology 2013; 87(11):6150-60. https://doi.org/10.1128/ JVI.03372-12.

32. Karypidou K, Ribone SR, Quevedo MA, Persoons L, Pannecouque $C$, Helsen $C$, et al. Synthesis, biological evaluation and molecular modeling of a novel series of fused 1,2, 3-triazoles as potential anticoronavirus agents. Bioorganic Medicinal Chemistry Letters 2018;28(21):3472-6. https://doi.org/10.1016/j.bmcl.2018.09.019.

33. UI Qamar MT, Alqahtani SM, Alamri MA, Chen LL. Structural basis of SARS-CoV-2 3CLpro and anti-COVID-19 drug discovery from medicinal plants. Journal of Pharmaceutical Analysis 2020; https://doi.org/10.20944/ preprints202002.0193.v1.

34. Fehr AR, and Perlman S. Coronaviruses: an overview of their replication and pathogenesis. In Coronaviruses (pp. 1-23). Humana Press, New York, NY; 2015. https://doi.org/10.1007/978-1-4939-2438-7_1.

35. Al-Tawfiq JA, Memish ZA. Managing MERS-CoV in the healthcare setting. Hospital Practice 2015;43(3):158-63. https://doi.org/10.1080/21548331.201 5.1074029 .

36. Ababneh M, Alrwashdeh M. Khalifeh M. Recombinant adenoviral vaccine encoding the spike 1 subunit of the Middle East Respiratory Syndrome Coronavirus elicits strong humoral and cellular immune responses in mice. Veterinary World 2019;12(10):1554-62. https://doi.org/10.14202/ vetworld.2019.1554-1562.

37. Li G, Fan Y, Lai Y, Han T, Li Z, Zhou P,... and Zhang Q. Coronavirus infections and immune responses. Journal of Medical Virology. 2020;92(4):424-432. https://doi.org/10.1002/jmv.25685.

38. Stebbing J, Phelan A, Griffin I, Tucker C, Oechsle O, Smith D, Richardson P. COVID-19: combining antiviral and anti-inflammatory treatments. Lancet Infectious Diseases 2020; 20(4):400-2. https://doi.org/10.1016/S14733099(20)30132-8.

39. Chhikara BS, Rathi B, Singh J and Poonam FNU. Corona virus SARSCoV-2 disease COVID-19: Infection, prevention and clinical advances of the prospective chemical drug therapeutics. Chemical Biology Letters 2020;7(1): 63-72.

40. Liu C, Zhou Q, Li Y, Garner LV, Watkins SP, Carter, LJ, et al. Research and Development on Therapeutic Agents and Vaccines for COVID-19 and Related Human Coronavirus Diseases. ACS Central Science 2020;6(3):31531. https://doi.org/10.1021/acscentsci.0c00272.

41. $\mathrm{Li}, \mathrm{G}$ and De Clercq, E. Therapeutic options for the 2019 novel coronavirus (2019-nCoV).Nature Reviews Drug Discovery 2020;19:149-50. https://doi. org/10.1038/d41573-020-00016-0

42. Wang M, Cao R, Zhang L, Yang X, Liu J, Xu M,... and Xiao G. Remdesivir and chloroquine effectively inhibit the recently emerged novel coronavirus (2019-nCoV) in vitro. Cell Research 2020;30(3): 269-71.

43. Barnard DL, Kumaki Y. Recent developments in anti-severe acute respiratory syndrome coronavirus chemotherapy. Future Viroloji 2011;6(5):615-31. https://doi.org/10.2217/fvl.11.33.

44. Shen L, Niu J, Wang C, Huang B, Wang W, Zhu N, et al. High-throughput screening and identification of potent broad-spectrum inhibitors of coronaviruses. Journal of Virology 2019; 93(12): e00023-19. https://doi. org/10.1128/JVI.00023-19.

45. Veljkovic V, Vergara-Alert J, Segalés J, Paessler S. Use of the informational spectrum methodology for rapid biological analysis of the novel coronavirus 2019-nCoV: prediction of potential receptor, natural reservoir, tropism and therapeutic/vaccine target. F1000 Research. 2020;9(52):1-12. https://doi. org/10.12688/f1000research.22149.2.

46. Ben-Shabat S, Yarmolinsky L, Porat D, and Dahan A. Antiviral effect of phytochemicals from medicinal plants: Applications and drug delivery strategies. Drug Delivery and Translational Research 2020;10:354-367. https://doi.org/10.1007/s13346-019-00691-6.

47. Cui $Q, D u R$, Liu M, and Rong L. Lignans and Their Derivatives from Plants as Antivirals. Molecules 2020;25(1):183.

48. Latha $\mathrm{N}$ and Pandit $\mathrm{M}$. In silico studies reveal potential antiviral activity of phytochemicals from medicinal plants for the treatment of COVID-19 infection. Preprint 2020. https://doi.org/10.21203/rs.3.rs-22687/v1.

49. Dhama K, Karthik K, Khandia R, Munjal A, Tiwari R, Rana R,... and Farag MR. Medicinal and therapeutic potential of herbs and plant metabolites/ extracts countering viral pathogens-current knowledge and future prospects. Current Drug Metabolism 2018;19(3):236-263.

50. Moradi MT, Rafieian-Kopaei M, and Karimi A. A review study on the effect of Iranian herbal medicines against in vitro replication of herpes simplex virus. Avicenna Journal of Phytomedicine 2016;6(5):506.

51. Parvez MK, Al-Dosari MS, Alam P, Rehman M, Alajmi MF and Alqahtani AS. The anti-hepatitis $B$ virus therapeutic potential of anthraquinones derived from Aloe vera. Phytotherapy Research 2019;33(11):2960-70.

52. Brochot A, Guilbot A, Haddioui L, and Roques C. Antibacterial, antifungaland antiviral effects of three essential oil blends. Microbiology Open 2017;6(4): e00459.

53. Venturi CR, Bordignon SADL, Roehe PM, Montanha JA, Cibulski SP, and Gosmann G. Chemical analysis and antiviral activity evaluation of Baccharis anomala. Natural Product Research 2018;32(16),1960-2. https://doi.org/10.1 080/14786419.2017.1354186.

54. Lelešius R, Karpovaitè A, Mickienẻ R, Drevinskas T, Tiso N, Ragažinskienẻ $\mathrm{O}, \ldots$ and Šalomskas, A. In vitro antiviral activity of fifteen plant extracts against avian infectious bronchitis virus. BMC Veterinary Research 2019;15(1):178.

55. Nolkemper S, Reichling J, Stintzing FC, Carle R, and Schnitzler P. Antiviral effect of aqueous extracts from species of the Lamiaceae family against Herpes simplex virus type 1 and type 2 in vitro. Planta Medica 2006;72(15):1378-82. 
56. Dimitrova Z, Dimov B, Manolova N, Pancheva S, llieva D, and Shishkov S. Antiherpes effect of Melissa officinalis L. extracts. Acta Microbiologica Bulgarica 1993;29:65-72

57. Geuenich S, Goffinet C, Venzke S, Nolkemper S, Baumann I, Plinkert P,... and Keppler OT. Aqueous extracts from peppermint, sage and lemon balm leaves display potent anti-HIV-1 activity by increasing the virion density. Retrovirology 2008;5(1):27.

58. Wölbling $\mathrm{RH}$, and Leonhardt K. Local therapy of herpes simplex with dried extract from Melissa officinalis. Phytomedicine 1994;1(1):25-31.

59. Koytchev R, Alken RG, and Dundarov S. Balm mint extract (Lo-701) for topical treatment of recurring herpes labialis. Phytomedicine 1999;6(4):225-30.

60. Pourghanbari G, Nili H, Moattari A, Mohammadi A, and Iraji A. Antiviral activity of the oseltamivir and Melissa officinalis $L$. essential oil against avian influenza A virus (H9N2). Virus Disease 2016;27(2):170-8.

61. Allahverdiyev A, Duran N, Ozguven M, and Koltas S. Antiviral activity of the volatile oils of Melissa officinalis L. against Herpes simplex virus type-2. Phytomedicine 2004;11(7-8): 657-61.

62. Schnitzler P, Schuhmacher A, Astani A, and Reichling J. Melissa officinalis oil affects infectivity of enveloped herpesviruses. Phytomedicine 2008;15(9):73440.

63. Byler KG, Ogungbe IV, and Setzer WN. In-silico screening for anti-Zika virus phytochemicals. Journal of Molecular Graphics and Modelling 2016;69:78-91.

64. Todorov D, Hinkov A, Shishkova K, and Shishkov S. Antiviral potential of Bulgarian medicinal plants. Phytochemistry Reviews 2014;13(2):525-38.

65. Chen SG, Leu YL, Cheng ML, Ting SC, Liu CC, Wang SD,... and Ho HY. Antienterovirus 71 activities of Melissa officinalis extract and its biologically active constituent rosmarinic acid. Scientific Reports 2017;7(1): 1-16.

66. Utomo RY, Ikawati M, Meiyanto E. Revealing the Potency of Citrus and Galangal Constituents to Halt SARS-CoV-2 Infection 2020. https://doi. org/10.20944/preprints202003.0214.v1.

67. Touraine RL, Vahanian N, Ramsey WJ, and Blaese RM. Enhancement of the herpes simplex virus thymidine kinase/ganciclovir bystander effect and its antitumor efficacy in vivo by pharmacologic manipulation of gap junctions. Human Gene Therapy 1998;9(16):2385-91. https://doi.org/10.1089/ hum.1998.9.16-2385.

68. Bergner P. Antiviral botanicals in herbal medicine. Medical Herbalism 2005;14(3):1-12

69. Manganelli RU, Zaccaro L, and Tomei PE. Antiviral activity in vitro of Urtica dioica L, Parietaria diffusa M. et K. and Sambucus nigra L. Journal of Ethnopharmacology 2005;98(3):323-7.

70. Glatthaar B, Saalmüller A, Haunschild J, and Amon A. Antiviral activity of a composition of Gentiana lutea L, Primula veris L, Sambucus nigra L, Rumex spec. and Verbena officinalis L.(Sinupret $($ ) ) against viruses causing respiratory infections. European Journal of Integrative Medicine 2009;1(4):258.

71. Porter RS, and Bode RF. A review of the antiviral properties of black elder (Sambucus nigra L.) products. Phytotherapy Research 2017;31(4):533-54.

72. Akram M, Tahir IM, Shah SMA, Mahmood Z, Altaf A, Ahmad K,... and Mehboob H. Antiviral potential of medicinal plants against HIV, HSV, influenza, hepatitisand coxsackievirus: A systematic review. Phytotherapy Research 2018;32(5):811-22.

73. Dong W, Wei X, Zhang F, Hao J, Huang F, Zhang C, and Liang W. (2014). A dual character of flavonoids in influenza $A$ virus replication and spread through modulating cell-autonomous immunity by MAPK signaling pathways. Scientific Reports 2014;4:7237.

74. Tang K, He S, Zhang X, Guo J, Chen Q, Yan F,... and Guo Y. Tangeretin, an extract from Citrus peels, blocks cellular entry of arenaviruses that cause viral hemorrhagic fever. Antiviral Research 2018;160:87-93.

75. Hu Z, Hu J, Ren F, Xu H, Tan M, Wang Q, and Ren J. Nobiletin, a novel inhibitor, inhibits HBsAg production and hepatitis B virus replication. Biochemical and Biophysical Research Communications 2020;523:802-8.

76. Khwaza V, Oyedeji OO, Aderibigbe BA. Antiviral activities of oleanolic acid and its analogues. Molecules 2018;23(9):2300.

77. Herrmann Jr EC, and Kucera LS. (1967). Antiviral Substances in Plants of the Mint Family (Labiatae). III. Peppermint (Mentha piperita) and other Mint Plants. Proceedings of the Society for Experimental Biology and Medicine 1967;124(3):874-8.

78. El-Awady SI, Essam T, Hashem A, Boseila AA, and Mohmmed AF. Assessment of antiviral activity for Lamiaceae family members against RNA and DNA virus models using cell-culture: in vitro study. World Journal of Medical Sciences 2014;11(1):111-9.

79. Nasr-Eldin MA, Abdelhamid A, and Baraka D. Antibiofilm and Antiviral Potential of Leaf Extracts from Moringa oleifera and Rosemary (Rosmarinus officinalis Lam.). Egyptian Journal of Microbiology 2017;52(1):129-39.

80. Battistini R, Rossini I, Ercolini C, Goria M, Callipo MR, Maurella $C, \ldots$ and Serracca L. (2019). Antiviral Activity of Essential Oils Against Hepatitis A Virus in Soft Fruits. Food and Environmental Virology 2019;11(1):90-5.

81. Gavanji S, Sayedipour SS, Larki B, and Bakhtari A. Antiviral activity of some plant oils against herpes simplex virus type 1 in Vero cell culture. Journal of Acute Medicine 2015;5(3):62-8

82. Giraldo HJA, Salazar DFS, Diaz SU, and Isaza JA. Inhibición del virus de Bronquitis Infecciosa Aviar mediante el uso de aceites esenciales. Revista Electrónica de Veterinaria 2017;18(10):1-9.

83. Cinatl J, Morgenstern B, Bauer G, Chandra P, Rabenau H, and Doerr HW. Glycyrrhizin, an active component of liquorice rootsand replication of SARSassociated coronavirus. The Lancet 2003;361(9374):2045-6.

84. Crance JM, Scaramozzino N, Jouan A, and Garin D. Interferon, ribavirin 6-azauridine and glycyrrhizin: antiviral compounds active against pathogenic flaviviruses. Antiviral Research 2003;58(1):73-9.

85. Fiore C, Eisenhut M, Krausse R, Ragazzi E, Pellati D, Armanini D, and Bielenberg J. Antiviral effects of Glycyrrhiza species. Phytotherapy Research: An International Journal Devoted to Pharmacological and Toxicological Evaluation of Natural Product Derivatives 2008;22(2):141-8.

86. Baltina LA, Kondratenko RM, Plyasunova OA, Pokrovskii AG, Tolstikov GA. Prospects for the creation of new antiviral drugs based on glycyrrhizic acid and its derivatives (a review). Pharmaceutical Chemistry Journal 2009;43(10):539-48.

87. Ashfaq UA, Masoud MS, Nawaz Z, and Riazuddin S. Glycyrrhizin as antiviral agent against Hepatitis $C$ Virus. Journal of Translational Medicine 2011;9(1):112.

88. Batiha GS, Beshbishy AM, El-Mleeh A, Abdel-Daim MM, and Devkota HP. Traditional uses, bioactive chemical constituentsand pharmacological and toxicological activities of Glycyrrhiza glabra L. Fabaceae). Biomolecules 2020;1-21.

89. Ghannad MS, Mohammadi A, Safiallahy S, Faradmal J, Azizi M, and Ahmadvand $Z$. The effect of aqueous extract of Glycyrrhiza glabra on herpes simplex virus 1. Jundishapur Journal of Microbiology 2014;7(7).

90. Yasmin AR, Chia SL, Looi QH, Omar AR, Noordin MM, and Ideris A. Herbal extracts as antiviral agents. In Feed Additives (pp. 115-132). Academic Press; 2020.

91. Huan CC, Wang HX, Sheng XX, Wang R, Wang X, and Mao X. (2017). Glycyrrhizin inhibits porcine epidemic diarrhea virus infection and attenuates the proinflammatory responses by inhibition of high mobility group box-1 protein. Archives of Virology 2017;162(6):1467-76.

92. Mamedov NA, Egamberdieva D. Phytochemical constituents and pharmacological effects of licorice: a review. In Plant and Human Health, Volume 3 (pp. 1-21). Springer, Cham; 2019.

93. lanevski A, Andersen, PI, Merits A, Bjørås M, and Kainov D. Expanding the activity spectrum of antiviral agents. Drug Discovery Today 2019;24(5):122428.

94. Pastorino G, Cornara L, Soares S, Rodrigues F, and Oliveira MBP. Liquorice (Glycyrrhiza glabra): A phytochemical and pharmacological review. Phytotherapy Research 2018;32(12):2323-39.

95. Sun ZG, Zhao TT, Lu N, Yang YA, and Zhu HL. Research Progress of Glycyrrhizic Acid on Antiviral Activity. Mini Reviews in Medicinal Chemistry 2019;19(10):826-32.

96. Rehman S, ljaz B, Fatima N, Muhammad SA, and Riazuddin S. Therapeutic potential of Taraxacum officinale against HCV NS5B polymerase: In-vitro and In silico study. Biomedicine and Pharmacotherapy 2016;83:881-91.

97. Gonçalves JLS, Lopes RC, Oliveira DB, Costa SS, Miranda MMFS, Romanos $M T V, \ldots$ and Wigg MD. In vitro anti-rotavirus activity of some medicinal plants used in Brazil against diarrhea. Journal of Ethnopharmacology 2005;99(3):403-7.

98. Ustun U, Ozcelik B, Baykal T. Bioactivities of Ethanolic Extract and its Fractions of Cistus laurifolius L. (Cistaceae) and Salvia wiedemannii Boiss. (Lamiaceae) Species. Pharmacognosy Magazine 2016;12(45):82-5 (Supplement 1). 
99. Ehrhardt C, Hrincius ER, Korte V, et al. A polyphenol rich plant extract, CYSTUS052, exerts anti influenza virus activity in cell culture without toxic side effects or the tendency to induce viral resistance. Antiviral Research 2007;76:38-47.

100. Kalus U, Grigorov A, Kadecki O, Jansen JP, Kiesewetter H, Radtke H. Cistus incanus (CYSTUS052) for treating patients with infection of the upper respiratory tract A prospective, randomised, placebo-controlled clinical study. Antiviral Research 2009;84:267-271.

101. Soltan MM, and Zaki AK. Antiviral screening of forty-two Egyptian medicinal plants. Journal of Ethnopharmacology 2009;126(1):102-7.

102. AMR (Alternative Medicine Review). Olive Leaf Monograph - Foundational Medicine Review 2009;14(1). http://www.altmedrev.com/archive/ publications/14/1/62.pdf

103. Lee-Huang S, Zhang L, Huang PL, Chang YT, and Huang PL. Anti-HIV activity of olive leaf extract (OLE) and modulation of host cell gene expression by HIV-1 infection and OLE treatment. Biochemical and Biophysical Research Communications 2003;307(4):1029-37. https://doi.org/10.1016/S0006291X(03)01292-0.

104. Motamedifar M, Nekoueian AA, and Moatari A. The effect of hydroalcoholic extract of olive leaves against herpes simplex virus type 1. Iranian Journal of Medical Sciences 2007;32(4): 222-6.

105. Zaher KS. In vitro studies on the antiviral effect of olive leaf against infectious laryngotracheitis virus. Global Veterinaria 2007;(1): 24-30.

106. Knipping K, Garssen J, and Van't Land B. An evaluation of the inhibitory effects against rotavirus infection of edible plant extracts. Virology Journal 2012;9(1):137-44.

107. Salih RH, Odisho SM, Al-Shammari AM, and Ibrahim OMS. Antiviral effects of olea europaea leaves extract and interferon-beta on gene expression of newcastle disease virus. Advances in Animal and Veterinary Sciences 2017;5(11):436-45.

108. Fredrickson WR. U.S. Patent No. 6,117,844. Washington, DC: U.S. Patent and Trademark Office, 2000.

109. Micol V, Caturla N, Pérez-Fons L, Más V, Pérez L, and Estepa A. The olive leaf extract exhibits antiviral activity against viral haemorrhagic septicaemia rhabdovirus (VHSV). Antiviral Research, 2005;66(2-3):129-36. https://doi. org/10.1016/j.antiviral.2005.02.005.

110. Loizzo MR, Saab AM, Tundis R, Statti GA, Menichini F, Lampronti I,... and Doerr, HW. Phytochemical analysis and in vitro antiviral activities of the essential oils of seven Lebanon species. Chemistry and Biodiversity 2008;5(3):461-70.

111. Li Y, Liu Y, Ma A, Bao $Y$, Wang M, and Sun Z. In vitro antiviral, antiinflammatoryand antioxidant activities of the ethanol extract of Mentha piperita L. Food Science and Biotechnology, 2017;26(6):1675-83.

112. Yamasaki K, Nakano M, Kawahata T, Mori H, Otake T, Ueda $\mathrm{N}, \ldots$ and Murata H. Anti-HIV-1 activity of herbs in Labiatae. Biological and Pharmaceutical Bulletin 1998;21(8):829-33.

113. Blank DE, de Oliveira Hübner S, Alves GH, Cardoso CA. L, Freitag RA, and Cleff MB. Chemical Composition and Antiviral Effect of Extracts of Origanum vulgare. Advances in Bioscience and Biotechnology 2019;10(07):188. https:// doi.org/10.4236/abb.2019.107014

114. Gilling DH, Kitajima M, Torrey JR, and Bright KR. Antiviral efficacy and mechanisms of action of oregano essential oil and its primary component carvacrol against murine norovirus. Journal of Applied Microbiology 2014;116(5):1149-63.

115. Zhang XL, Guo YS, Wang CH, Li GQ, Xu JJ, Chung, HY,... and Wang GC. Phenolic compounds from Origanum vulgare and their antioxidant and antiviral activities. Food Chemistry 2014;152:300-6.
116. Schnitzler $P$, Koch $C$, and Reichling J. Susceptibility of drug-resistant clinical herpes simplex virus type 1 strains to essential oils of ginger, thyme, hyssopand sandalwood. Antimicrobial Agents and Chemotherapy 2007;51(5):1859-62.

117. Salah-Fatnassi KBH, Slim-Bannour A, Harzallah-Skhiri F, Mahjoub MA, Mighri Z, Chaumont JP, and Aouni M. Activités antivirale et antioxydante in vitro d'huiles essentielles de Thymus capitatus (L.) Hoffmans. and Link de Tunisie. Acta Botanica Gallica. 2010;157(3):433-44.

118. Duran N, Kaya A, Gulbol Duran G, Eryilmaz N. In vitro antiviral effect of the essential oils of Thymbra spicata L. on Herpes simplex virus type 2. ICAMS $2012-4^{\text {th }}$ International Conference on Advanced Materials and Systems 2012.

119. Andleeb R, Ashraf A, Muzammil S, Naz S, Asad F, Ali T,... and Mahboob S. Analysis of bioactive composites and antiviral activity of Iresine herbstii extracts against Newcastle disease virus in ovo. Saudi Journal of Biological Sciences 2020;27(1):335-40.

120. Kubiça TF, Alves SH, Weiblen R, and Lovato LT. In vitro inhibition of the bovine viral diarrhoea virus by the essential oil of Ocimum basilicum (basil) and monoterpenes. Brazilian Journal of Microbiology 2014;45(1):209-14.

121. Chiang LC, Ng LT, Cheng PW, Chiang W, and Lin CC. Antiviral activities of extracts and selected pure constituents of Ocimum basilicum. Clinical and Experimental Pharmacology and Physiology 2005;32(10): 811-6.

122. Valadares, YM, Brandão GC, Kroon EG, Souza Filho JD, Oliveira AB, and Braga FC. Antiviral activity of Solanum paniculatum extract and constituents. Zeitschrift für Naturforschung C 2009;64(11-12):813-8.

123. Kaziyama VM, Fernandes MJB, and Simoni IC. Atividade antiviral de extratos de plantas medicinais disponíveis comercialmente frente aos herpesvírus suíno e bovino. Revista Brasileira de Plantas Medicinais 2012;14(3):522-8. https://doi.org/10.1590/S1516-05722012000300015.

124. Gabaglio S, Alvarenga N, Cantero-González G, Degen R, Ferro E. A, Langjahr $\mathrm{P}, \ldots$ and Sotelo $\mathrm{PH}$. A quantitative PCR assay for antiviral activity screening of medicinal plants against Herpes simplex 1. Natural Product Research 2019;1-5. https://doi.org/10.1080/14786419.2019.1675064.

125. Akhtar S. Use of Tinospora cordifolia in HIV infection. Indian Journal of Pharmacology 2010;42(1):57.

126. Mazumder A, Raghavan K, Weinstein J, Kohn KW, and Pommier Y. Inhibition of human immunodeficiency virus type-1 integrase by curcumin. Biochemical Pharmacology 1995;49(8):1165-70.

127. Mounce BC, Cesaro T, Carrau L, Vallet T, and Vignuzzi M. Curcumin inhibits Zika and chikungunya virus infection by inhibiting cell binding. Antiviral Research 2017;142,148-157.

128. Parsania M, Rezaee MB, Monavari SH, Jaimand K, Mousavi Jazayeri SM, Razazian M, and Nadjarha MH. Evaluation of antiviral effects of sumac (Rhus coriaria L.) fruit extract on acyclovir resistant Herpes simplex virus type 1. Medical Science Journal of Islamic Azad Univesity-Tehran Medical Branch 2017;27(1):1-8.

129. Gharabolagha AF, Sabahia F, Karimib M, Kamalinejadc M, Mirshahabid $H$, Nasab S. DM, and Ahmadif NA. Effects of Rhus coriaria L.(sumac) extract on hepatitis B virus replication and $\mathrm{Hbs}$ Ag secretion. Journal of Reports in Pharmaceutical Sciences 2018; 7(1):100-7.

130. Thuy BTP, My TTA, Hai NTT, Hieu LT, Hoa TT, Thi Phuong Loan H,... and Hue N. V. Investigation into SARS-CoV-2 Resistance of Compounds in Garlic Essential Oil. ACS Omega 2020;5(14):8312-20.https://doi.org/10.1021/ acsomega.0c00772. 


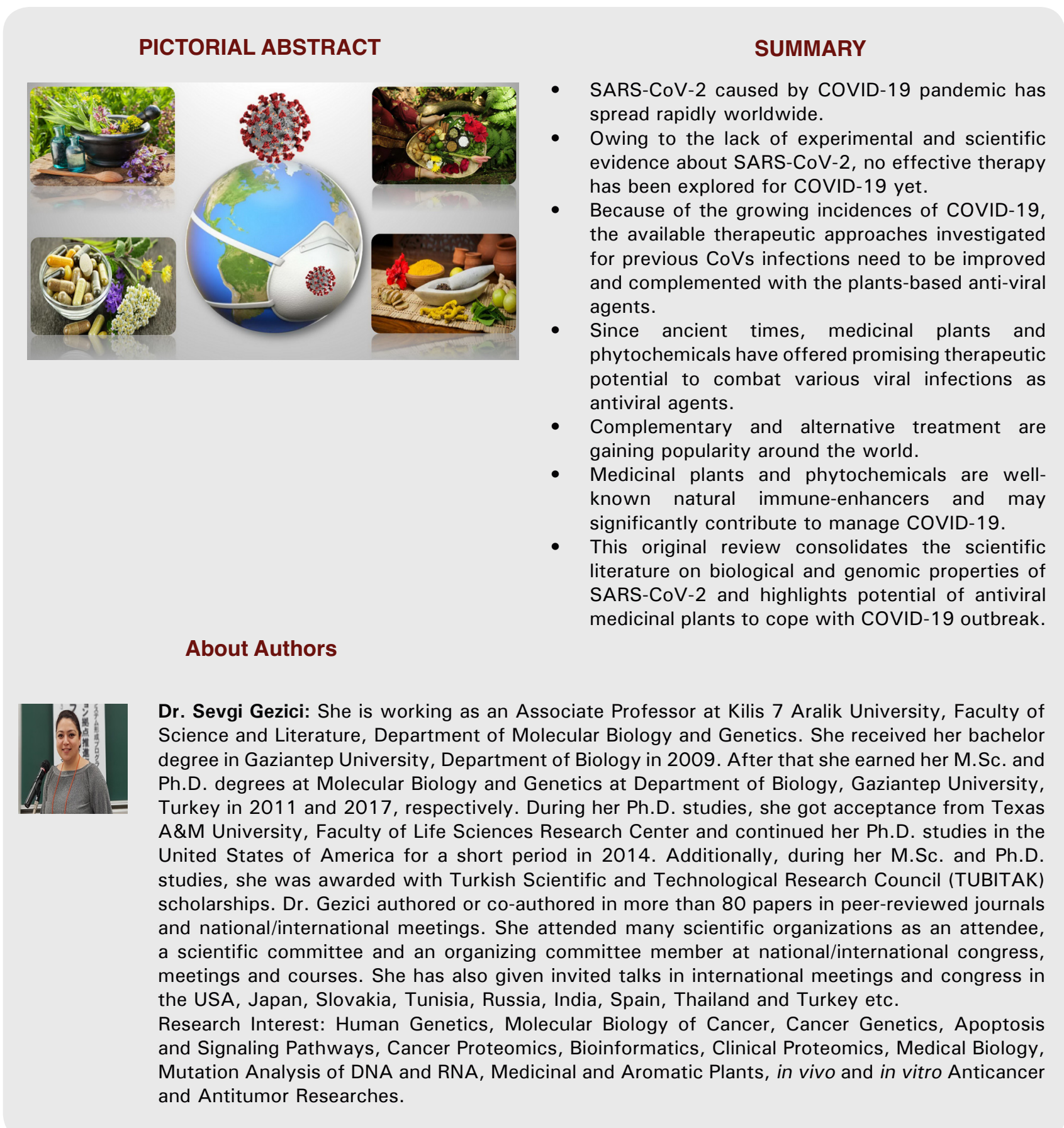


Prof. Dr. Nazim Sekeroglu: He earned his BsC in Agricultural Engineering; Prof. Dr. Sekeroglu earned his PhD degree on Medicinal and Aromatic Plants (MAPs) at Cukurova University, Turkey. His main interest is Medicinal and Aromatic Plants since his undergraduate education. He is currently a fulltime professor at Kilis 7 Aralik University, Agricultural Faculty and Department of Horticulture. He published over 100 peer-reviewed articles and still active on his research area. He managed or participated many national and international scientific projects on MAPs. Additionally, he has organized many international scientific meetings, including congress, symposiums and workshops as chairperson. Furthermore, he is the founder of the Association of Medicinal and Aromatic Plants of Mediterranean (AMAPMED), also he is general coordinator of Global Federation of Medicinal and Aromatic Plants (GOFMAP), a worldwide non-profit organizations gathering associations related 'Medicinal and Aromatic Plants'. Moreover, he is a member of scientific commissions on Medicinal and Aromatic Plants at Food, Agriculture, Forestry and Health Ministries in Turkey. He has visited more than 70 different countries for scientific purposes. Currently, he is dean of Kilis 7 Aralik University, Agricultural Faculty.

Cite this article: Gezici S, Sekeroglu N. Novel SARS-CoV-2 and COVID-2019 Outbreak: Current Perspectives on Plant-Based Antiviral Agents and Complementary Therapy Indian J of Pharmaceutical Education and Research. 2020;54(3s):s442-s456. 